\title{
ANALIZING FACTOR THAT AFFECTING IMPORT OF MAIZE IN INDONESIA \\ ANALISIS FAKTOR-FAKTOR YANG MEMPENGARUHI IMPOR JAGUNG DI INDONESIA
}

\author{
Elpawati, Iwan Aminudin, Raditya Audayuda
}

\begin{abstract}
The purpose of The study is to identify the factor that affecting import of maize in Indonesia, Ana to analyze The factor that affecting import of maize in Indonesia. The data used in The Study is Time series data from 1990 to 2014 sourced from BPS(Badan Pusat Statistik) and Kementrian Pertanian. The method used in The Study is linear regression analysis using SPSS 18 software. Statistics Test that used in this Study including $R^{2}, F$-test, and T-test. In this Study we can concluded that $R^{2}$ test value is 0,703 that means 70,3\% import of maize explained by variable that used in model, which is: maize production (produksi jagung), maize consumption (konsumsi jagung), maize domestic prize (harga jagung domestik), maize import prize (harga jagung impor), and Rupiah to US Dollar currency (Nilai tukar rupiah terhadap dollar Amerika), and remaining 29,7\% remains explained by another variable that exclude by this model.

After all The testing, results shows all variable in The model affecting maize import simultaneously, and partial Test shows maize production, maize consumption, maize domestic prize, and Rupiah to US Dollar currency partially affecting import of maize in Indonesia, and maize import prize variable didn't affect import of maize in Indonesia.
\end{abstract}

Keyword: Maize, impor, impor of maize, International Trade

\section{PENDAHULUAN}

Jagung (Zea mays L) merupakan salah satu tanaman pangan yang banyak di produksi di Indonesia selain dari tanaman padi yang merupakan tanaman yang menghasilkan beras, yaitu pangan pokok bagi masyarakat Indonesia. Jagung merupakan salah satu tanaman penghasil karbohidrat selain gandum dan padi, yang banyak dikonsumsi oleh masyarakat di Indonesia, dan menjadi makanan pokok di beberapa daerah timur Indonesia, dan juga beberapa negara seperti Amerika. Jagung selain di konsumsi langsung sebagai makanan pokok, dapat digunakan juga sebagai bahan utama dari pakan ternak. Tidak hanya dikonsumsi langsung, jagung juga digunakan dalam banyak industri olahan yang menghasilkan berbagai macam produk turunan.

Jagung yang banyak digunakan keberadaannya membuat ketersediaannya dibutuhkan oleh masyarakat, jumlah dari banyaknya konsumsi jagung di Indonesia berikut ini adalah tabel yang menunjukkan konsumsi dari jagung di Indonesia pada 15 tahun terakhir.

Tabel 1. Konsumsi Jagung di Indonesia.

\begin{tabular}{ccc}
\hline Tahun & $\begin{array}{c}\text { Konsumsi } \\
\text { (000 ton) }\end{array}$ & $\begin{array}{c}\text { Pertumbuhan } \\
\text { Konsumsi (\%) }\end{array}$ \\
\hline 2000 & 5.891 & - \\
2001 & 1.908 & $-67,61 \%$ \\
2002 & 2.785 & $45,97 \%$ \\
2003 & 2.944 & $5,70 \%$ \\
2004 & 3.039 & $3,24 \%$ \\
2005 & 3.150 & $3,64 \%$ \\
2006 & 7.956 & $152,59 \%$ \\
\hline
\end{tabular}




\begin{tabular}{lll}
\hline 2007 & 3.625 & $-54,44 \%$ \\
2008 & 3.533 & $-2,54 \%$ \\
2009 & 3.992 & $13,01 \%$ \\
2010 & 4.844 & $21,32 \%$ \\
2011 & 3.992 & $-17,57 \%$ \\
2012 & 4.720 & $18,23 \%$ \\
2013 & 4.852 & $2,80 \%$ \\
2014 & 5.379 & $10,84 \%$ \\
\hline
\end{tabular}

Sumber: Badan Pusat Statistik, 2016 (diolah)

Konsumsi jagung pada kenyataan lapangan tercatat lebih besar dari catatan konsumsi seperti pada diatas diduga karena mengingat banyak industri pakan ternak skala kecil/rumah tangga yang belum tercakup dalam penggunaan pakan oleh industri. Pengolahan jagung untuk pakan (self mix) yang dilakukan oleh rumah tangga usaha peternakan, diduga

jumlahnya cukup besar. Disamping itu banyak jagung yang dikonsumsi di luar rumah tangga sebagai makanan jadi seperti untuk snack, jagung bakar, jagung untuk sayuran, atau makanan lain berbahan baku jagung.

Konsumsi jagung di Indonesia sendiri akan terpenuhi melalui produksi yang dilakukan oleh para petani di Indonesia dengan kegiatan memproduksi jagung pada lahan mereka atau bertani. Kegiatan bertani ini akan menghasilkan jagung yang bisa digunakan untuk segala kebutuhan konsumsi dari Jagung di Indonesia. Berikut ini merupakan produksi jagung pada periode 15 tahun terakhir.

Tabel 2. Produksi Jagung di Indonesia.

\begin{tabular}{ccc}
\hline Tahun & $\begin{array}{c}\text { Produksi } \\
\text { (ribu ton) }\end{array}$ & $\begin{array}{c}\text { Pertumbuhan } \\
\text { Produksi (\%) }\end{array}$ \\
\hline 2000 & 9.667 & - \\
2001 & 9.347 & $-3,31 \%$ \\
2002 & 9.585 & $2,55 \%$ \\
2003 & 10.886 & $13,57 \%$ \\
2004 & 11.225 & $3,11 \%$ \\
2005 & 12.524 & $11,57 \%$ \\
2006 & 11.609 & $-7,31 \%$ \\
2007 & 13.288 & $14,46 \%$ \\
2008 & 16.317 & $22,80 \%$ \\
2009 & 17.630 & $8,05 \%$
\end{tabular}

\begin{tabular}{ccc}
2010 & 18.328 & $3,96 \%$ \\
2011 & 17.643 & $-3,74 \%$ \\
2012 & 19.387 & $9,88 \%$ \\
2013 & 18.512 & $-4,51 \%$ \\
2014 & 19.008 & $2,68 \%$ \\
\hline \multicolumn{2}{l}{ Sumber: Badan Pusat Statistik, 2016 (diolah) }
\end{tabular}

Produksi jagung di Indonesia yang mengalami tren meningkat, namun pertumbuhannya tidak terlalu besar apabila dibandingkan dengan konsumsinya. Adapun pertumbuhan yang tidak terlalu besar diduga diakibatkan karena persaingan dengan tanaman lain ataupun diakibatkan karena adanya konversi lahan di beberapa daerah yang digunakan untuk kebutuhan lain, serta tidak besarnya pertumbuhan produksi diduga diakibatkan oleh perubahan iklim global seperti adanya musim kemarau basah, yang menyebabkan tanaman jagung tidak banyak ditanam dan digantikan dengan tanaman lain seperti padi, yang dinilai akan lebih menguntungkan apabila dibudidayakan pada saat itu.

Produksi jagung ini merupakan hal yang mendukung untuk tercukupinya konsumsi dari jagung di Indonesia, dan melihat angka dari tabel konsumsi dan produksi di atas, seharusnya produksi dari jagung di Indonesia dapat mencukupi kebutuhan konsumsi di Indonesia, bisa dilihat dengan melihat jumlah produksi yang lebih besar dari jumlah konsumsinya. Melihat dari hal tersebut, seharusnya jagung di Indonesia dapat dicukupi oleh produksi yang dilakukan, namun pemerintah tetap melakukan impor jagung pada tahun 1990 hingga 2014, adapaun volume impor pada periode 15 tahun terakhir dapat dilihat pada tabel berikut:

Tabel 3. Volume Impor Jagung di Indonesia.

Tahun Volume Pertumbuhan




\begin{tabular}{ccc}
\hline & $\begin{array}{c}\text { Impor (ribu } \\
\text { ton) }\end{array}$ & $\begin{array}{c}\text { Volume impor } \\
(\%)\end{array}$ \\
\hline 2000 & $1.264,58$ & - \\
2001 & $1.035,80$ & $-18,09 \%$ \\
2002 & $1.154,06$ & $11,42 \%$ \\
2003 & $1.345,45$ & $16,58 \%$ \\
2004 & $1.088,93$ & $-19,07 \%$ \\
2005 & 185,60 & $-82,96 \%$ \\
2006 & $1.775,32$ & $856,55 \%$ \\
2007 & 701,95 & $-60,46 \%$ \\
2008 & 264,67 & $-62,30 \%$ \\
2009 & 338,80 & $28,01 \%$ \\
2010 & $1.527,52$ & $350,86 \%$ \\
2011 & $3.207,66$ & $109,99 \%$ \\
2012 & $1.805,39$ & $-43,72 \%$ \\
2013 & $3.194,42$ & $76,94 \%$ \\
2014 & $3.175,36$ & $-0,60 \%$ \\
\hline Sumber: Badan Pusat Statistik 2016 (diolah)
\end{tabular}

Volume impor jagung di Indonesia pada periode 15 tahun terakhir seperti yang dapat dilihat pada tabel menunjukkan tren yang meningkat. impor jagung di Indonesia tetap dilakukan diduga dikarenakan adanya kebutuhan permintaan jagung yang digunakan untuk keperluan industri dengan kriteria kualitas tertentu yang tidak dapat dipenuhi oleh produksi jagung yang dilakukan oleh petani lokal.

Impor jagung di Indonesia yang memiliki tren yang meningkat volumenya akan membuat kekhawatiran bagi para seluruh pelaku yang terlibat di industri jagung ini, dikarenakan berdasarkan data di atas, jumlah produksi dari jagung di Indonesia yang dihasilkan memenuhi konsumsinya, namun tetap dilakukan impor jagung dengan jumlah yang tidak sedikit, tentu akan mengancam bagi para petani lokal mengingat persaingan dari produksi jagung akan bertambah, selain itu, impor jagung akan membutuhkan biaya yang akan membebani negara dengan semakin banyaknya devisa negara yang digunakan untuk mendatangkan jagung impor tersebut dengan jumlah yang tidak sedikit. dan tren pada 15 tahun terakhir dapat dilihat pada tabel berikut:



Sumber: Badan Pusat Statistik dan Bank Indonesia, 2016 (diolah)

Nilai dari jagung impor yang dikeluarkan dengan menggunakan devisa negara dapat dilihat memiliki tren yang semakin meningkat, dan melihat tren yang memiliki nilai semakin meningkat setiap tahun, akan lebih baik apabila devisa negara tersebut bisa di alokasikan untuk sektor lain, mengingat Indonesia memiliki potensi untuk bisa memenuhi kebutuhan konsumsi jagung di Indonesia dengan produksinya yang semakin meningkat.

Menurut Sri Adiningsih (1993) produksi adalah suatu proses menambah nilai barang dengan mengubah input menjadi output. Secara teknis kegiatan produksi dilakukan dengan mengombinasikan beberapa input untuk menghasilkan sejumlah output.

Menurut Hutabarat (1996) Impor juga bisa dikatakan sebagai perdagangan 
dengan cara memasukkan barang dari luar negeri ke wilayah Indonesia dengan memenuhi ketentuan yang berlaku.

Rosseti, et al (2009) mengemukakan penurunan jumlah produksi tanaman pangan disebabkan banyaknya lahan pertanian yang beralih fungsi ke non pertanian dan konstruksi sehingga mempengaruhi besarnya impor untuk mencukupi kebutuhan kedelai dalam negeri.

Menurut Rita (2009) Impor tergantung pada produksi dalam negeri dan harga dalam negeri. Penurunan produksi nasional dan peningkatan harga suatu produk dalam negeri akan menyebabkan kecenderungan untuk melakukan impor. Jadi, jumlah produksi memiliki pengaruh negatif dan signifikan terhadap volume impor.

Permintaan adalah berbagai jumlah barang yang diminta oleh konsumen pada berbagai tingkat harga pada periode tertentu. Teori permintaan menjelaskan hubungan antara jumlah barang yang diminta oleh konsumen antara jumlah barang yang diminta dengan harga yang patuh menurut hukum permintaan (Kunawangsih \& Pracoyo, 2006).

Mankiw (2013) mengungkapkan beberapa faktor yang mempengaruhi impor, begitu pula dengan ekspor suatu negara, yaitu:

a) Selera konsumen untuk barang-barang produksi dalam dan luar negeri.

b) Harga barang di dalam negeri

c) Nilai tukar dimana orang-orang dapat menggunakan mata uang domestik untuk membeli mata uang asing.

d) Pendapatan konsumen di dalam dan luar negeri.

e) Biaya transportasi barang dari satu negara ke negara lain f) Kebijakan pemerintah terhadap perdagangan internasional.

Menurut Sukirno (2004) penentu impor yaitu apabila barang-barang dari luar negeri mutunya lebih baik, atau hargaharganya lebih murah, daripada barangbarang yang sama yang dihasilkan di dalam negeri, maka akan terdapat kecenderungan bahwa negara tersebut akan mengimpor lebih banyak barang dari luar negeri.

Berdasarkan permasalahan di atas, maka peneliti bermaksud untuk meneliti tentang "Faktor-faktor yang mempengaruhi impor jagung di Indonesia".

\section{METODOLOGI PENELITIAN}

Dalam penelitian ini, untuk menganalisis besarnya pengaruh variabel yang mempengaruhi impor jagung di Indonesia digunakan metode Analisis Regresi Linear Berganda, serta digunakan uji asumsi klasik dan uji hipotesis. Regresi digunakan untuk mengetahui hubungan antara variabel bebas (produksi jagung, konsumsi jagung, harga jagung domestik, harga jagung impor, dan nilai tukar rupiah terhadap dolar Amerika) terhadap variabel terikat yaitu impor jagung. Pengolahan data pada variabel dalam penelitian ini menggunakan Microsoft Excel 2013 dan Statistical Product and Service Solutions (SPSS) versi 18.

Jenis data yang digunakan adalah data sekunder. Jenis data sekunder yang digunakan adalah data time series dengan rentang waktu tahun 1990-2014 (25 tahun) mengenai impor jagung Indonesia, produksi jagung Indonesia, konsumsi jagung Indonesia, harga jagung domestik, 
harga jagung impor, dan kurs rupiah terhadap dolar Amerika. Sumber data sekunder yang digunakan diperoleh dari Badan Pusat Statistik dan Kementrian Pertanian

\section{ANALISIS DAN PEMBAHASAN}

\section{Uji Asumsi Klasik}

Sebelum dilakukan uji regresi, variabel yang ditentukan akan diuji dengan menggunakan uji BLUE (Best Linear Unbiased Estimate) untuk melihat apakah data terdistribusi normal dengan menggunakan uji normalitas, tidak terjadi heteroskedastisitas, multikolinearitas, dan autokorelasi. Uji ini secara keseluruhan menggambarkan ada atau tidaknya gangguan pada model regresi yang

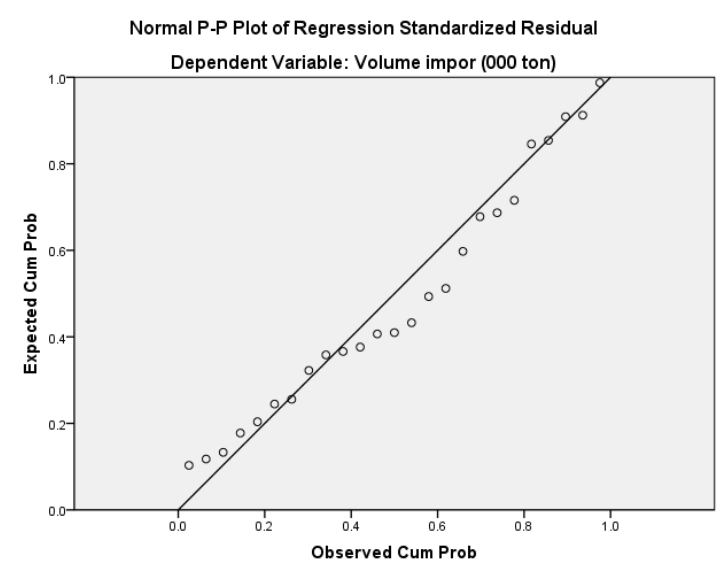

\section{Gambar . Normal P-Plot of Regression Standarized Residual}

Sumber: data sekunder (diolah)

Gambar grafik P-Plot diatas memperlihatkan titik - titik data menyebar di sekitar garis normal serta mengikuti arah garis diagonal, sehingga dapat dikatakan bahwa data terdistribusi secara normal dan model telah memenuhi asumsi normalitas.

Selain menggunakan grafik P-Plot, uji normalitas dapat diuji dengan menggunakan uji Kolmogrov - Smirnov $(\mathrm{K}-\mathrm{S})$. Hasil dari uji normalitas akan digunakan dan memenuhi syarat analasisi regresi linear berganda berbasis OLS (Ordinary Least Square).

\section{Uji Normalitas}

Uji normalitas dilakukan untuk menguji variabel dependen dan independen dalam model mempunyai distribusi yang normal atau tidak. Model yang baik memiliki distribusi yang normal atau mendekati normal, dimana salah satu cara untuk melihat normal atau tidaknya adalah dengan melihat normal probability plot yang membandingkan distribusi kumulatif dari distribusi normal. Model yang mempunyai distribusi normal akan membentuk garis diagonal. Hasil uji normalitas dapat dilihat dalam grafik PPlot berikut ini:

menggunakan uji Kolmogrov - Smirnov dapat dilihat di tabel berikut:

Tabel 5. Uji Kolmogrov - Smirnov

\begin{tabular}{|l|r|}
\hline & Unstandarized Residual \\
\hline $\mathrm{N}$ & 25 \\
\hline $\begin{array}{l}\text { Asymp. Sig. } \\
\text { (2-tailed) }\end{array}$ &, 748 \\
\hline
\end{tabular}

Sumber: Data Sekunder (diolah)

Dari hasil uji diatas, data memiliki nilai signifikan sebesar 0,748 dimana nilai tersebut lebih besar dari 0,05 , sehingga dapat diartikan bahwa data tersebut terdistribusi secara normal.

\section{Uji Heteroskedastisitas}

Uji Heteroskedastisitas digunakan untuk melihat bias atau tidaknya dari hasil regresi, dengan cara melihat grafik plot antara nilai prediksi variabel terikat (ZPRED) dengan nilai residualnya (SRESID). Hasil uji akan ditampilkan pada gambar berikut 


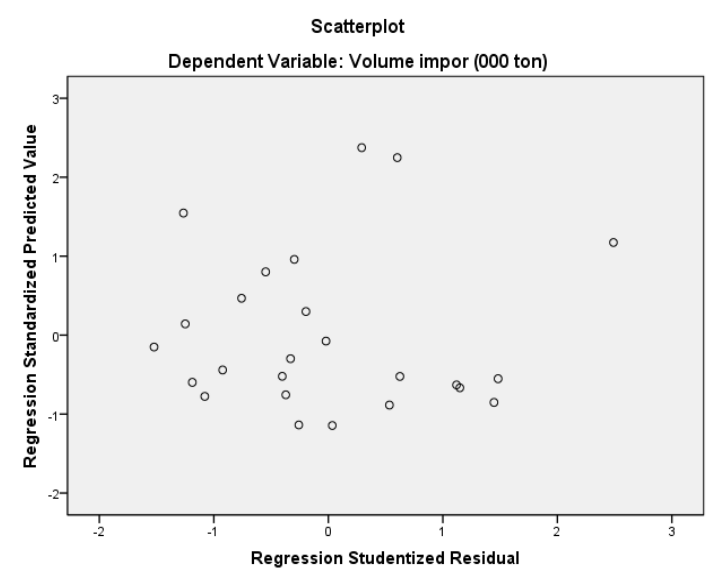

Gambar. Scatterplot Uji

Heteroskedastisitas.

Sumber: Data Sekunder (diolah)

Gambar diatas menunjukkan diagram scatterplot memiliki titik yang menyebar secara acak baik diatas maupun dibawah nilai 0 pada sumbu Y. Hal ini menandakan tidak terjadi heteroskedastisitas pada model regresi, dan model regresi layak untuk dipakai. analisis menggunakan scatterplot dapat memiliki kekurangan apabila jumlah pengamatan semakin sedikit, maka akan mempengaruhi hasil dari scatterplot menjadi sulit untuk diiterpretasikan. Oleh karena itu, untuk membuat uji heteroskedastisitas menjadi semakin akurat bisa dilakukan uji glesjer, yang dapat dilihat pada tabel berikut:

\section{Tabel 6. Uji Glesjer}

\begin{tabular}{lrr}
\hline \multicolumn{1}{c}{ Variabel } & \multicolumn{1}{c}{ T } & \multicolumn{1}{c}{ Sig. } \\
\hline Produksi &, 415 &, 683 \\
Konsumsi & $-1,130$ &, 273 \\
Harga &, 097 &, 924 \\
Domestik & & \\
Harga Impor & 186 &, 854 \\
Kurs & -1489 &, 153 \\
\hline Sumber: Data Sekunder (diolah) &
\end{tabular}

Tabel diatas menunjukkan bahwa variabel Produksi, Konsumsi, Harga Domestik, Harga Impor, dan Kurs memiliki nilai signifikan 0,$683 ; 0,273$; 0,$924 ; 0,854$; dan 0,153 , dimana seluruh nilai signifikan dari variabel tersebut bernilai lebih besar dari 0,05, yang artinya tidak didapati masalah heteroskedastisitas dalam model regresi ini, dengan kata lain seluruh variabel independen yang ada pada model ini memiliki sebaran yang sama atau homogen.

\section{Uji Multikolinearitas}

Uji multikolinearitas dilakukan untuk melihat apakah ada korelasi antar variabel dependen dalam model regresi, dimana model regresi yang baik tidak terjadi korelasi antar variabel independennya. Menurut Ghozali (2011), multikolinearitas dapat dilihat dari nilai tolerance dan lawannya variance inflaction fator (VIF). Nilai yang umum dipakai untuk menunjukkan adanya multikolinearitas adalah nilai tolerance $\geq$ 0,10 atau sama dengan nilai $\mathrm{VIF} \leq 10$. Uji multikolineartias diolah dengan menggunakan SPSS 18 yang memiliki hasil sebagai berikut:

Tabel 7. Uji Multikolinearitas

\begin{tabular}{lrr}
\hline \multicolumn{1}{c}{ Variabel } & \multicolumn{2}{c}{ Colinearity Statistics } \\
& Tolerance & \multicolumn{1}{c}{ VIF } \\
\hline Produksi &, 897 & 1,115 \\
Konsumsi &, 408 & 7,756 \\
Harga &, 101 & 9,914 \\
Domestik & & \\
Harga Impor &, 405 & 2,409 \\
Kurs &, 324 & 3,084 \\
\hline Sumber: Data Sekunder (diolah) &
\end{tabular}

Tabel diatas menunjukkan bahwa semua variabel independen diatas memiliki nilai variance inflaction factor $(\mathrm{VIF}) \leq 10$ dan nilai tolerace $\geq 0,10$ sehingga dapat disimpulkan bahwa model regresi yang digunakan tidak memiliki masalah multikolinearitas.

\section{Hasil Uji Autokorelasi}

Uji autokorelasi digunakan untuk mengetahui adakah korelasi antara kesalahan periode $\mathrm{t}$ dengan periode $\mathrm{t}$ sebelumnya dalam suatu model regresi. Metode yang digunakan untuk menguji autokorelasi adalah menggunakan uji 
Durbin - Watson, dimana hasi dari uji tersebut adalah sebagai berikut:

Tabel 8. Uji Durbin - Watson

\begin{tabular}{|c|c|c|c|c|}
\hline Model & $\mathbf{R}$ & R Square & $\begin{array}{l}\text { Adjusted R } \\
\text { Square }\end{array}$ & 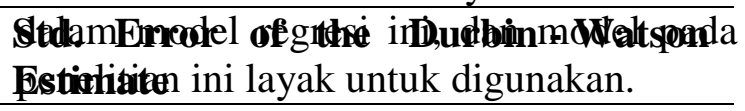 \\
\hline 1 & ,875 & ,765 & ,703 & 509,769 \\
\hline
\end{tabular}

hasil dari uji Durbin - Watson (DW) memiliki nilai sebesar 1,844 . Hasil dari nilai ini akan dibandingkan dengan nilai Durbin - Watson tabel dengan input signifikansi 0,05 , jumlah data (n) 25 , dan jumlah variabel independen (k) sebanyak 5 sehingga akan didapatkan nilai dL sebesar 0,953 dan nilai dU sebesar 1,886. Hasil perbandingan dari nilai menghasilkan nilai $\mathrm{dL}<\mathrm{DW}<\mathrm{dU}$, yaitu $0,953<1,844<$ 1,886

Ghozali (2011) mengemukakan jika nilai $\mathrm{dL}<\mathrm{DW}<\mathrm{dU}$ maka ketentuan deteksi korealasi tidak dapat disimpulkan. Apabila nilai dari uji tersebut tidak dapat disimpulkan, maka cara lain untuk melakukan deteksi autokorelasi adalah dengan menggunakan Run Test, dimana hasil dari uji tersebut dapat dilihat pada tabel berikut:

Tabel 9. Uji Run Test

\begin{tabular}{lr}
\hline & $\begin{array}{c}\text { Unstandarized } \\
\text { Residual }\end{array}$ \\
\hline Test Value & $-116,255$ \\
Cases $<$ Test & 12 \\
Value & 13 \\
Cases >= Test & \\
Value & 25 \\
Total Cases & 10 \\
Number of Runs & $-1,220$ \\
$Z$ &, 223 \\
Asymp. Sig (2 - \\
tailed)
\end{tabular}

Berdasarkan tabel diatas, hasil dari nilai signifikansi pada Run Test adalah sebesar 0,223, dimana hasil itu bernilai

lebih besar jika dibandingkan dengan nilai batas dari tetapan uji Run Test yaitu 0,05. Apabila nilai tersebut lebih besar dari nilai tetapan Run Test, maka bisa disimpulkan bahwa tidak ditemukannya autokorelasi

Penulis menggunakan analisis regresi liner berganda untuk menjawab permasalahan penelitian yang dijabarkan sebelumnya. Perhitungan regresi linear berganda yang dilakukan dengan menggunakan sebuah software yang bernama SPSS 18, agar tercapainya tujuan untuk mencari faktor apa saja yang berpengaruh terhadap impor jagung di Indonesia. Hasil dari perhitungan regresi adalah sebagai berikut

Tabel 10. Regresi Faktor-faktor yang Mempengaruhi Impor Jagung di Indonesia

\begin{tabular}{|c|c|c|}
\hline \multirow{2}{*}{ Model } & \multicolumn{2}{|c|}{$\begin{array}{l}\text { Unstandarized } \\
\text { Coefficients }\end{array}$} \\
\hline & B & $\begin{array}{c}\text { Std. } \\
\text { Error }\end{array}$ \\
\hline (Constant) & 2079,594 & 768,147 \\
\hline Produksi &,- 390 & 112 \\
\hline Konsumsi & ,202 & ,299 \\
\hline Harga & 1,337 &, 000 \\
\hline Domestik & & \\
\hline Harga Impor & $-2,067$ &, 000 \\
\hline Kurs & $-1,437$ & 051 \\
\hline \multicolumn{3}{|c|}{ Sumber: Data Sekunder (diolah) } \\
\hline $\begin{array}{l}\text { Berdasa } \\
\text { diatas, dapat } \\
\text { yang dihasil } \\
\text { adalah: } \\
\mathrm{Y}=2079,59 \\
1,337 \mathrm{X}_{3}-2,( \\
\text { Dimana: } \\
\mathrm{Y}=\text { Impor Ja } \\
\mathrm{X}_{1}=\text { Produksi } \\
\text { ton) }\end{array}$ & $\begin{array}{l}\text { hasil regres } \\
\text { apulkan mo } \\
\text { dalam pei } \\
390 \mathrm{X}_{1}+ \\
-1,437 \mathrm{X} \\
\text { di Indonesi } \\
\text { g dalam } \mathrm{N}\end{array}$ & $\begin{array}{l}\text { dari tabel } \\
\text { el regresi } \\
\text { litian ini } \\
202 \mathrm{X}_{2}+\end{array}$ \\
\hline
\end{tabular}


$\mathrm{X}_{2}=$ Konsumsi Jagung dalam Negeri (000 ton)

$\mathrm{X}_{3}=$ Harga Jagung Domestik (Rp/000 ton)

$\mathrm{X}_{4}=$ Harga Jagung Impor (Rp/000 ton)

$\mathrm{X}_{5}=$ Nilai Tukar Rupiah terhadap Dolar

Amerika (Rp/US\$)

Interpretasi dari hasil model regresi diatas adalah sebagai berikut:

a) Nilai koefisien konstanta (a) sebesar 2079,594. Nilai ini berarti apabila seluruh variabel bebas yaitu Produksi Jagung, Konsumsi Jagung, Harga Jagung Domestik, Harga Jagung Impor, dan Nilai Tukar Rupiah terhadap Dolar Amerika bernilai nol, maka bersar dari variabel terikat (impor jagung) memiliki nilai sebesar 2079,594 ribu ton.

b) Koefisien Produksi Jagung $\left(\mathrm{X}_{1}\right)$ bernilai -0,390, artinya apabila nilai $\mathrm{X}_{1}$ mengalami kenaikan sebesar seribu ton, maka impor jagung di Indonesia akan menurun sebesar 0,390 ribu ton, dengan asumsi variabel lain bernilai tetap.

c) Koefisien Konsumsi Jagung $\left(\mathrm{X}_{2}\right)$ bernilai 0,202 , artinya apabila nilai $\mathrm{X}_{2}$ mengalami kenaikan sebesar seribu ton, maka impor jagung di Indonesia akan meningkat sebesar 0,202 ribu ton, dengan asumsi variabel lain bernilai tetap.

d) Koefisien Harga Jagung Domestik $\left(\mathrm{X}_{3}\right)$ bernilai 1,337 , artinya apabila nilai $\mathrm{X}_{3}$ mengalami kenaikan sebesar seribu ton, maka impor jagung di Indonesia akan meningkat sebesar 1,337 ribu ton, dengan asumsi variabel lain bernilai tetap.

e) Koefisien Harga Jagung Impor $\left(\mathrm{X}_{4}\right)$ bernilai $-2,067$, artinya apabila nilai $\mathrm{X}_{4}$ mengalami kenaikan sebesar seribu ton, maka impor jagung di Indonesia akan menurun sebesar 2,067 ribu ton, dengan asumsi variabel lain bernilai tetap.

f) Koefisien Nilai tukar Rupiah terhadap Dolar Amerika $\left(\mathrm{X}_{5}\right)$ bernilai -1,437, artinya apabila nilai $\mathrm{X}_{5}$ mengalami kenaikan sebesar seribu ton, maka impor jagung di Indonesia akan menurun sebesar 1,437 ribu ton, dengan asumsi variabel lain bernilai tetap.

\section{Uji Statistik}

Hasil dari perhitungan uji signifikansi faktor yang mempengaruhi impor jagung adalah sebagai berikut:

\section{Uji Koefisien Determinasi $\left(\mathbf{R}^{\mathbf{2}}\right)$}

Uji koefisien determinasi ini digunakan untuk melihat seberapa besar variabel faktor-faktor yang dipilih dalam penelitian ini mampu menjelaskan impor jagung Indonesia, berikut tabel hasil uji koefisien determinasi penelitian ini:

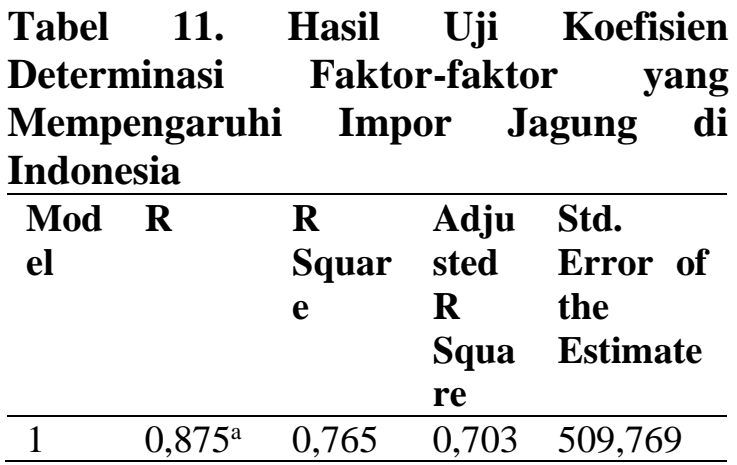

Sumber: Data sekunder (diolah)

Dari tabel hasil uji koefisien determinasi diatas, nilai dari koefisien determinasi dari persamaan regresi penelitian ini adalah sebesar 0,765 dengan nilai koefisien determinasi yang disesuaikan sebesar 0,703.Koefisien determinasi yang digunakan dalam menjelaskan persamaan ini adalah koefisien determinasi yang disesuaikan (adjusted $\mathrm{R}^{2}$ ) yang memiliki nilai sebesar 0,703 yang berarti variabel independen dalam penelitian ini yaitu produksi jagung, konsumsi jagung, harga jagung domestik, harga jagung impor, dan nilai tukar rupiah terhadap Dolar Amerika mampu menjelaskan variabel dependen yaitu impor jagung di Indonesia sebanyak 
$70,3 \%$ sementara sisanya $29,7 \%$ dijelaskan oleh variabel lain yang tidak dimasukkan dalam model penelitian ini.

\section{Uji Hipotesis Secara Simultan (Uji F)}

Nilai Koefisien Determinasi diketahui senilai 0,703 , setelah didapatkan nilai dari Koefisiensi Determinasi tersebut, diperlukan Uji statistik $F$. Uji ini digunakan untuk menunjukkan apakah semua variabel independen atau bebas yang dimasukkan ke dalam model mempunyai pengaruh secara bersamasama terhadap variabel dependennya. Uji ini melihat perbandingan antara nilai $F_{\text {hitung }}$ dengan $F_{\text {tabel }}$ seperti yang akan dijelaskan pada tabel berikut:

Tabel 12. Hasil Uji F Analisis Faktor-faktor yang mempengaruhi Impor Jagung di Indonesia

\begin{tabular}{llllll}
\hline Model & Sum of Squares & Df & Mean Square & F & Sig. \\
\hline $\begin{array}{l}\text { Regres } \\
\text { sion }\end{array}$ & 1,607 & 5 & 3214315,570 & 12,369 &, 000 \\
$\begin{array}{l}\text { Residu } \\
\text { al }\end{array}$ & 0,4937436635 & 19 & 259865,086 & & \\
Total & 2,101 & 24 & & & \\
\hline
\end{tabular}

Sumber: Data Sekunder (diolah)

Hasil uji $\mathrm{F}$ mennunjukkan bahwa tingkat signifikan $5 \%$, df1 $=5$ dan df $2=$ 19, maka akan di dapat nilai $F_{\text {hitung }}$ sebesar 12,369. Nilai tersebut jika dibandingkan dengan $F_{\text {tabel }}$ yaitu sebesar 2,740 mempunyai nilai yang lebih besar dengan nilai probabilitas sebesar 0,000 dimana nilai tersebut dibawah nilai signifikansi 0,05 . Kesimpulannya adalah produksi jagung, konsumsi jagung, harga jagung domestik, harga jagung impor, dan nilai tukar rupiah terhadap Dolar Amerika secara simultan atau bersama-sama mempunyai pengaruh terhadap impor jagung di Indonesia.

\section{Uji Hipotesis Parsial (Uji T)}

Uji $\mathrm{T}$ dilakukan untuk menunjukkan seberapa jauh pengaruh satu variabel independen secara individu dalam menjelaskan variasi variabel dependen dengan cara membandingkan nilai thitung dengan $t_{\text {tabel}}$, dengan hasil uji sebagai berikut:

\section{Tabel 13. Regresi Faktor-faktor yang Mempengaruhi Impor Jagung di Indonesia}

\begin{tabular}{|l|r|r|r|r|r|}
\hline \multirow{2}{*}{ Model } & \multicolumn{2}{|c|}{$\begin{array}{c}\text { Unstandarized } \\
\text { Coefficients }\end{array}$} & $\begin{array}{c}\text { Standarized } \\
\text { Coefficients }\end{array}$ & \multicolumn{1}{c|}{ t } & \multirow{2}{*}{ Sig. } \\
\cline { 2 - 4 } & \multicolumn{1}{|c|}{ B } & \multicolumn{1}{c|}{ Std. Error } & \multicolumn{1}{c|}{ Beta } & & \\
\hline (Constant) & 2079,594 & 768,147 & & 2,707 &, 014 \\
\hline Produksi &,- 390 &, 112 & $-1,838$ & $-3,490$ &, 002 \\
\hline Konsumsi &, 202 &, 299 &, 299 & 2,548 &, 020 \\
\hline Harga Domestik & 1,337 &, 000 &,- 229 &,- 655 &, 520 \\
\hline Harga Impor & $-2,067$ &, 000 & 2,663 & 5,255 &, 000 \\
\hline Kurs & $-1,437$ &, 051 &,- 055 & $-2,817$ &, 001 \\
\hline & & & & & \\
\hline
\end{tabular}

Sumber: Data Sekunder (diolah)

Pada tingkat kepercayaan 95\%, didapatkan nilat $t_{\text {tabel }}$ sebesar 2,064 menggunakan nilai df dengan tingkat signifikansi $5 \%$.

a) Tabel 13 menunjukkan nilai thitung untuk variabel produksi sebesar -3490 . Nilai thitung tersebut lebih besar dari 
ttabel yang bernilai 2,064 (-3,490> $2,064)$, serta memiliki nilai signifikansi lebih kecil dari nilai $\alpha(0,002<0,05)$ maka dapat disimpulkan bahwa H0 ditolak dan $\mathrm{Ha}$ diterima, variabel produksi memiliki pengaruh negatif dan signifikan terhadap impor jagung di Indonesia.

b) Tabel 13 menunjukkan nilai thitung untuk variabel konsumsi sebesar 2,548.

Nilai tersebut lebih besar dari tabel yang bernilai 2,064 $(2,548>2,064)$, serta memiliki nilai signifikansi lebih kecil dari nilai $\alpha(0,020<0,05)$ maka dapat disimpulkan bahwa $\mathrm{HO}$ ditolak dan $\mathrm{Ha}$ diterima, variabel konsumsi memiliki pengaruh positif dan signifikan terhadap impor jagung di Indonesia.

c) Tabel 13 menunjukkan nilai thitung untuk variabel harga jagung domestik sebesar -0,655. Nilai thitung tersebut lebih kecil dari $t_{\text {tabel }}$ yang bernilai 2,064 (-0,655 < 2,064), serta memiliki nilai signifikansi lebih besar dari nilai $\alpha(0,520>0,05)$ maka dapat disimpulkan bahwa H0 diterima dan Ha ditolak, variabel harga jagung domestik tidak berpengaruh dan tidak signifikan terhadap impor jagung di Indonesia.

d) Tabel 13 menunjukkan nilai thitung untuk variabel harga jagung impor sebesar 5,255. Nilai tersebut lebih besar dari $t_{\text {tabel }}$ yang bernilai sebesar 2,064 (5,255 > 2,064), serta memiliki nilai signifikansi lebih kecil dari $\alpha$ $(0,000<0,05)$ maka dapat disimpulkan bahwa H0 ditolak dan Ha diterima, variabel harga jagung impor berpengaruh positif dan signifikan terhadap impor jagung di Indonesia.

e) Tabel 13 menunjukkan nilai thitung untuk variabel nilai tukar rupiah terhadap dolar Amerika sebesar -2,817. Nilai tersebut lebih besar dari nilai $t_{\text {tabel }}$ yang bernilai $2,064(2,817>2,064)$, serta memiliki nilai signifikansi lebih kecil dari nilai $\alpha(0,001<0,05)$ maka dapat disimpulkan bahwa H0 ditolak dan Ha diterima, variabel nilai tukar rupiah terhadap dolar Amerika negatif dan signifikan terhadap impor jagung di Indonesia.

\section{Analisis Faktor - Faktor yang Mempengaruhi Impor Jagung di Indonesia}

Berdasarkan hasil regresi dan hasil uji statistik mengenai faktor-faktor yang mempengaruhi impor jagung di Indonesia dapat dijelaskan pengaruh antara variabel produksi jagung, konsumsi jagung, harga jagung domestik, harga jagung impor, dan nilai tukar rupiah terhadap dolar Amerika, dengan pembahasan sebagai berikut

\section{Produksi Jagung $\left(\mathrm{X}_{1}\right)$}

Hasil olah data variabel produksi jagung adalah sebagai berikut:

Tabel 14. Hasil olah data variabel Produksi Jagung

\begin{tabular}{llll}
\hline Variabel & $\begin{array}{l}\text { Hasil } \\
\text { Regresi }\end{array}$ & $\begin{array}{l}\text { Hasil } \\
\text { Uji T }\end{array}$ & $\begin{array}{l}\text { Nilai } \\
\text { Tabel }\end{array}$ \\
\hline Produksi & $-0,390$ & $-3,490$ & 2,064 \\
Jagung & & & \\
\hline
\end{tabular}

Hasil analisis regresi menunjukkan bahwa koefisien regresi variabel produksi jagung (X1) bernilai -0,390 yang berarti bahwa peningkatan produksi sebesar seribu ton akan menurunkan impor sebesar 0,390 ribu ton. Nilai $t$ hitung yang lebih besar dari $t$ tabel menandakan bahwa variabel produksi jagung memiliki pengaruh signifikan terhadap impor jagung di Indonesia.

Hal yang sama terjadi pada penelitian yang dilakukan oleh Arastika (2015) yang berjudul "Analisis Faktorfaktor yang Mempengaruhi Impor Gula di Indonesia" menerangkan bahwa produksi gula memiliki pengaruh negatif dan signifikan terhadap impor gula di 
Indonesia dan Singgih dan I Wayan dalam jurnal "Pengaruh Produksi, Jumlah Penduduk, PDB, dan Kurs Dollar Terhadap Impor Jagung Indonesia" (2015) menyatakan bahwa produksi jagung dalam negeri dapat mempengaruhi impor jagung secara simultan.

Produksi jagung nasional memiliki peran dalam impor jagung, karena apabila terjadi kekurangan produksi di dalam negeri akan menyebabkan tidak dapat dicukupinya kebutuhan akan jagung dan apabila semakin rendah produksi jagung dalam negeri, tentu membuat akan membuat konsumsi jagung tidak dapat dipenuhi lagi kebutuhannya oleh produksi dalam negeri dalam jangka waktu kedepannya, dan salah satu cara menutup kebutuhan akan jagung tersebut adalah dengan melakukan impor. Impor jagung akan semakin membesar apabila produksi dalam negeri tidak mencukupi untuk konsumsinya, sebaliknya apabila produksi dalam negeri semakin meningkat maka akan membuat impor jagung semakin sedikit, sejalan dengan teori perdagangan internasional yang menyatakan bahwa produksi satu komoditi yang mempunyai kekurangan absolut akan mengimpor dari yang negara yang memiliki keunggulan absolut.

Jagung jenis yang tidak mampu ataupun tidak dapat diproduksi dalam negeri namun dibutuhkan oleh pasar domestik juga bisa menyebabkan adanya impor jagung yang dilakukan pemerintah untuk tetap dapat memenuhi seluruh kebutuhan konsumsi pasar.

Apabila negara terus menerus melakukan impor tentu akan membuat pengeluaran devisa negara yang besar secara terus menerus yang sejatinya devisa negara tersebut bisa digunakan untuk kebutuhan lain yang kiranya lebih di perlukan.

\section{Konsumsi Jagung $\left(\mathrm{X}_{2}\right)$}

Hasil olah variabel Konsumsi Jagung adalah sebagai berikut:

Tabel 15. Hasil olah data variabel Konsumsi Jagung

\begin{tabular}{llll}
\hline Variabel & $\begin{array}{l}\text { Hasil } \\
\text { Regresi }\end{array}$ & $\begin{array}{l}\text { Hasil } \\
\text { Uji T }\end{array}$ & $\begin{array}{l}\text { Nilai T } \\
\text { Tabel }\end{array}$ \\
\hline $\begin{array}{l}\text { Konsumsi } \\
\text { Jagung }\end{array}$ & 0,202 & 2,548 & 2,064 \\
\hline
\end{tabular}

Hasil analisis regresi menunjukkan bahwa koefisien regresi variabel Konsumsi Jagung (X2) bernilai sebesar 0,202 yang berarti bahwa peningkatan Konsumsi Jagung sebesar seribu ton akan menaikkan impor jagung sebesar 0,202 ribu ton. Nilai $\mathrm{t}$ hitung yang lebih besar dari $\mathrm{t}$ tabel menandakan bahwa variabel konsumsi jagung memiliki pengaruh signifikan terhadap impor jagung di Indonesia.

Hal yang sama terjadi pada penelitian yang dilakukan oleh Febiansyah (2015) yang berjudul "Respon Impor Kedelai Terhadap Konsumsi Kedelai, Kurs, dan Harga Kedelai Impor di Indonesia", menerangkan bahwa konsumsi memiliki pengaruh positif dan signifikan.

Dengan meningkatnya konsumsi atau permintaan suatu komoditas dalam sebuah negara, maka negara akan berusaha memenuhi kebutuhan konsumsinya dengan melakukan produksi lebih banyak, namun apabila produksi tidak dapat mengejar pertumbuhan konsumsi jagung dalam negeri, salah satu cara pemenuhannya adalah dengan melakukan impor, sejalan dengan teori perdagangan internasional dimana perdagangan internasional dapat terjadi karena adanya perbedaan dari permintaan dan penawaran suatu negara.

Jagung yang dikonsumsi di Indonesia tidak hanya untuk kebutuhan rumah tangga, namun juga untuk kebutuhan industri. Revenia (2014) menyatakan bahwa alasan sebuah industri pakan melakukan impor jagung adalah karena terdapat perbedaan jenis jagung 
yang dibutuhkan, buruknya sistem pemasaran, dan efisiensi.

\section{Harga Jagung Domestik $\left(\mathbf{X}_{3}\right)$}

Hasil olah variabel harga jagung domestik adalah sebagai berikut:

Tabel 16. Hasil olah data variabel Harga Jagung Domestik

\begin{tabular}{llll}
\hline Variabel & $\begin{array}{l}\text { Hasil } \\
\text { Regresi }\end{array}$ & $\begin{array}{l}\text { Hasil } \\
\text { Uji T }\end{array}$ & $\begin{array}{l}\text { Nilai } \\
\text { Tabel }\end{array}$ \\
\hline Harga & 1,337 & $-0,655$ & 2,064 \\
Jagung & & & \\
Domestik & & & \\
\hline
\end{tabular}

Hasil analisis regresi menunjukkan bahwa koefisien regresi variabel harga jagung domestik (X3) bernilai sebesar 1,377 yang berarti bahwa setiap peningkatan harga jagung domestik sebesar 1 rupiah akan menaikkan impor jagung sebesar 1,377 ribu ton. Nilai $t$ hitung yang lebih kecil dari $t$ tabel menandakan bahwa variabel harga jagung domestik tidak berpengaruh dan tidak signifikan.

Jika harga pada jagung domestik meningkat, masyarakat akan cenderung untuk mengkonsumsi jagung impor dimana hal tersebut akan membuat pemerintah akan berusaha memenuhi kebutuhan jagung impor lebih banyak dengan menambah jumlah impor.

Hal yang sama terjadi pada jurnal penelitian yang dilakukan oleh Lisa Revania (2014) yang berjudul "Analisis Faktor-faktor yang Mempengaruhi Impor Jagung di Indonesia Periode Tahun 19822012" yang menerangkan bahwa harga jagung domestik tidak berpengaruh signifikan terhadap impor jagung di Indonesia. Utomo (2012) dalam Jurnal "Dampak Imor dan Ekspor Jagung Terhadap Produktivitas Jagung Di Indonesia" menyatakan bahwa harga akan memparuhi besarnya impor jagung.

Sejalan dengan hukum permintaan yang menyatakan bahwa semakin rendah harga suatu barang maka semakin banyak permintaan terhadap barang tersebut, sebaliknya semakin tinggi harga barang akan membuat semakin sedikit permintaan terhadap barang tersebut.

Purba, dkk(2012) menyatakan harga dan luas panen jagung akan membantu menaikkan penawaran dan akan mengakibatkan stabilnya harga jagung.

\section{Harga Jagung Impor $\left(\mathbf{X}_{4}\right)$}

Hasil olah variabel harga jagung impor adalah sebagai berikut:

Tabel 17. Hasil olah data variabel Harga Jagung Impor

\begin{tabular}{llll}
\hline Variabel & $\begin{array}{l}\text { Hasil } \\
\text { Regresi }\end{array}$ & $\begin{array}{l}\text { Hasil } \\
\text { Uji T }\end{array}$ & $\begin{array}{l}\text { Nilai T } \\
\text { Tabel }\end{array}$ \\
\hline Harga & $-2,067$ & 5,255 & 2,064 \\
Jagung & & & \\
Impor & & & \\
\hline
\end{tabular}

Hasil analisis regresi menunjukkan bahwa koefisien regresi variabel harga jagung impor (X4) bernilai sebesar -2,067 yang berarti bahwa setiap peningkatan 1 rupiah harga jagung impor akan menurunkan impor sebanyak 2,067 ribu ton. Nilai t hitung yang lebih besar dari t tabel menandakan bahwa variabel harga jagung impor memiliki pengaruh yang signifikan.

Hal yang sama terjadi pada penelitian yang dilakukan oleh Febiansyah (2015) yang berjudul "Respon Impor Kedelai Terhadap Konsumsi Kedelai, Kurs, dan Harga Kedelai Impor di Indonesia", menerangkan bahwa harga kedelai impor berpengaruh negatif terhadap impor kedelai di Indonesia. Utomo (2012) dalam Jurnal "Dampak Imor dan Ekspor Jagung Terhadap Produktivitas Jagung Di Indonesia" menyatakan bahwa harga akan memparuhi besarnya impor jagung

Impor jagung dapat terjadi bukan hanya karena ketidakmampuan pemenuhan konsumsi oleh produksi lokal, namun bisa 
dikarenakan harga jagung impor tersebut lebih rendah, sehingga impor jagung tersebut tetap dilakukan, Surbakti (2013) menyatakan bahwa impor jagung dilakukan dikarenakan harga jagung impor lebih murah, bukan karena adanya kekurangan pada segi pasokan.

Sejalan dengan teori Ceteris Paribus yang menjelaskan bahwa semakin rendah harga suatu komoditi maka jumlah barang yang diminta akan semakin meningkat, sebaliknya apabila suatu harga komoditas semakin tinggi, maka jumlah barang yang diminta akan semakin berkurang.

Surbakti (2013) menyatakan bahwa impor jagung dilakukan dikarenakan harga jagung impor lebih murah, bukan karena adanya kekurangan pada segi pasokan.

\section{Nilai Tukar Rupiah terhadap Dolar Amerika (X5)}

Hasil olah variabel nilai tukar rupiah terhadap dolar Amerika adalah sebagai berikut:

Tabel 18. Hasil olah data variabel Kurs Rupiah terhadap Dolar Amerika

\begin{tabular}{llll}
\hline Variabel & $\begin{array}{l}\text { Hasil } \\
\text { Regresi }\end{array}$ & $\begin{array}{l}\text { Hasil } \\
\text { Uji T }\end{array}$ & $\begin{array}{l}\text { Nilai } \\
\text { Tabel }\end{array}$ \\
\hline Kurs & $-1,437$ & $-2,817$ & 2,064 \\
Rupiah & & & \\
terhadap & & & \\
Dolar & & & \\
Amerika & & & \\
\hline
\end{tabular}

Hasil analisis regresi menunjukkan bahwa koefisien regresi variabel nilai tukar rupiah terhadap dolar (X5) bernilai sebesar $-1,437$ yang berarti bahwa setiap peningkatan nilai tukar rupiah sebesar 1 rupiah maka akan menurunkan impor jagung sebesar 1,437 ribu ton. Nilai $\mathrm{t}$ hitung yang lebih besar dari $t$ tabel menandakan bahwa variabel nilai tukar rupiah terhadap dolar Amerika memiliki pengaruh signifikan.

Hal yang sama terjadi pada penelitian yang dilakukan oleh Namira (2015) yang berjudul "Analisis Faktor- faktor yang Mempengaruhi Impor Beras di Indonesia", menerangkan bahwa nilai tukar rupiah terhadap dolar Amerika berpengaruh negatif terhadap impor beras di Indonesia.

Impor yang berkaitan erat dengan nilai tukar mata uang antara suatu negara dengan negara lain. Apabila terjadi penurunan mata uang dalam negeri yaitu Rupiah, maka akan terjadi naiknya nilai mata uang asing yaitu Dolar, akan membuat negara yang akan melakukan impor yaitu Indonesia akan mengeluarkan lebih banyak Rupiah untuk membeli jagung yang di impor sehingga akan mengakibatkan volume impor jagung di Indonesia akan menurun.

sebaliknya apabila terjadi kenaikan dari Rupiah, maka nilai dari Dolar akan menurun dan mengakibatkan lebih sedikit Rupiah yang dikeluarkan negara untuk melakukan impor jagung dan akan berakibat pada naiknya volume impor jagung di Indonesia.

Aditya Bangga dan Saskara (2013) dalam Indraswari (2015) menyatakan bahwa depresiasi atau apresiasi nilai mata uang dalam sistem kurs mengambang, akan mengakibatkan perubahan keatas ekspor maupun impor. Jika kurs mengalami penurunan, yaitu nilai mata uang dalam negeri melemah sedangkan nilai mata uang asing menguat kursnya akan menyebabkan ekspor meningkat dan impor cenderung menurun (Imamudin Yuliadi ,2008) dalam Indraswari (2015).

\section{KESIMPULAN}

Berdasarkan analisis dan pembahasan hasil penelitian mengenai faktor-faktor yang mempengaruhi impor jagung di Indonesia dengan menggunakan analisis uji regresi linear berganda, maka dapat ditarik kesimpulan sebagai berikut:

a) Hasil penelitian menunjukkan bahwa variabel yang berpengaruh terhadap impor jagung di Indonesia adalah produksi jagung, konsumsi jagung, harga jagung domestik, harga jagung 
impor, dan nilai tukar rupiah terhadap dolar Amerika secara bersama - sama.

b) Hasil penelitian menyatakan bahwa variabel Konsumsi jagung dan harga jagung impor berpengaruh positif dan signifikan pada tingkat kepercayaan 95\%, produksi jagung dan nilai tukar rupiah terhadap dolar Amerika berpengaruh negatif dan signifikan pada tingkat kepercayaan $95 \%$, dan variabel harga jagung domestik tidak berpengaruh dan tidak signifikan terhadap impor jagung di Indonesia.

\section{DAFTAR PUSTAKA}

Adiningsih, S. dan Mulyadi. 1993. Alternatif teknik rehabilitasi dan pemanfaatan lahan alang-alang. Pusat Penelitian Tanah dan Agroklimat. Badan Litbang Pertanian.

Anonim. Departemen Pertanian. Outlook Komoditas Subsektor Tanaman Pangan: Jagung. Jakarta: Departemen Pertanian, 2015.

Arastika, Gega Indah. Analisis FaktorFaktor Yang Mempengaruhi Impor Gula Di Indonesia. [Skripsi]. UIN Syarif Hidayatullah Jakarta. Fakultas Sains dan Teknologi. Program Studi Agribisnis. 2015.

Badan Pusat Statistik (BPS). Statistik Indonesia 1990-2014. Jakarta: BPS, $\quad 1990-2014$

Bajracharya, Mahima, Mahesh Sapkota, Surya Mani Dhungana. Socioeconomic analysis of maize seed production in Arghakhanchi district of Nepal. Journal of Maize Research and Development vol 2 (2016): No. 1, hal $144-150$.

Bank Indonesia. Nilai Kurs Tahun $2000-$ 2014. www.bi.go.id. Diakses pada tanggal 20 Januari 2016.

Bhandari, Ganashyam, Buddhi Bahadur Achhami, Tika Bahadur Karki,
Balram Bhandari, Gopal Bhandari. Survey of Maize Post Harvest Losses and Its Management Practices in Western Hills in Nepal. Journal of Maize Reaserch and Development, Vol.1 (2015): No. 1, Hal. 98 - 105.

Bussay, Atilla. Marijn van der Velde, Davide Fumagalli, Lorenzo Seguini. Improving operational maize yield forecasting in Hungary. Agricultural Systems Elsevier Journal vol 141 (2015): Hal 94 - 106.

Erwidodo, Hermanto, dan Herena Pudjihastuti. Impor Jagung : Perlukah tarif impor diberlakukan? Jawaban analisis simulasi. Jurnal Agro Ekonomi vol 21, 2003; No 2: Hal 175 - 195

Febiansyah, Andika. Respon Impor Kedelai Terhadap Konsumsi Kedelai, Kurs, dan Harga Kedelai Impor di Indonesia. [Skripsi]. UIN Syarif Hidayatullah Jakarta. Fakultas Sains dan Teknologi. Program Studi Agribisnis. 2015.

Ghozali, Imam. Aplikasi Analisis Multivariate Dengan Program IBM SPSS 19. Semarang: Badan Penerbit Universitas Diponegoro, 2011.

Grace Sintari Siregar. 2009. Analisis Respon Penawaran Komoditas Jagung dalam rangka Mencapai Swasembada jagung di Indonesia. Bogor: Institut pertanian Bogor.

Hady, Hamdy. Ekonomi Internasional Teori dan Kebijakan Keuangan Internasional. Jakarta: Ghalia Indonesia, 2004.

Hapsari, Triana Dewi, M Muslich M, Nuhfil Hanani AR, dan Rini Dwi Atuti. Dampak konversi jagung sebagai etanol di pasar dunia terhadap ketersediaan jagung di Indonesia. Jurnal Agro Ekonomi 
Vol 27, 2009; No. 2 : Hal 193 211.

Hutabarat, R. 1996. Transaksi Ekspor Impor. Jakarta: Erlangga.

Indraswari, Putri Anggara dan Nyoman Dinar Setiawina. Pengaruh Jumlah Produksi, Kurs Dollar AS, dan PDB Pertanian Terhadap Impor Jagung Indonesia Tahun 1985 2012. E-Jurnal EP UNUD Vol 4, 2014; No. 2 : Hal. 113 - 120.

Kariyasa, Ketut dan Bonar M Sinaga. Faktor - faktor yang mempengaruhi perilaku pasar jagung di Indonesia. Jurnal Agro Ekonomi Vol 22, 2004; No. 2 : Hal $167-194$.

KC, Govind, Tika B. Karki, Jiban Shrestha, Buddi B. Achhami. Status and Prospects of Maize Reaserch in Nepal. Journal of Maize Reaserch and Development, Vol.1 (2015): No. 1, Hal. 1-9.

Mankiw, N.Gregory, dkk. Pengantar Ekonomi Makro. Jakarta: Salemba Empat, 2013.

Pengantar

Ekonomi Mikro. Jakarta: Salemba Empat, 2013.

Namira, Yona. Analisis Faktor-Faktor Yang Mempengaruhi Impor Beras $\mathrm{Di}$ Indonesia. [Skripsi]. UIN Syarif Hidayatullah Jakarta. Fakultas Sains dan Teknologi. Program Studi Agribisnis. 2015.

Purba, Rudi Hartono, HM Mozart B Darus, dan, Tavi Supriana. Faktor - faktor yang mempengaruhi Penawaran Jagung di Sumatera Utara. Jurnal Agribisnis USU, 2013.

Purwono dan Rudi Hartono. 2005. Bertanam Jagung Unggul. Penebar Swadaya, Jakarta.

Putri, Aulisa Isnaini, Bonar M Sinaga, Nia Kurniawati, dan Hastuti. Dampak Kebijakan Tarif Impor Terhadap
Pasar Jagung di Indonesia. Jurnal Ekonomi Pertanian, Sumber Daya dan Lingkungan vol. 2, 2014 : Hal. 68 - 80 .

Rachman, B. dan S. K. Dermoredjo.2003. Dinamika Harga dan Perdagangan Beras. Ekonomi Padi dan Beras Indonesia. Badan Penelitian dan Pengembangan Pertanian. Departemen Pertanian, Jakarta.

Revenia, Lisa. Analisis Faktor - faktor yang mempengaruhi Impor Komoditas Jagung di Indonesia Periode Tahun 1982 - 2012. Economics Development Analysis Journal Vol 1, 2014.

Rosseti, M. D., R. R. Hill, B. Johansson, A. Dunkin and R. G. Ingals. 2009. Economic Evaluation of The Increase In Production Capacity Of A High Technology Products Manufacturing Cell Using Discrete Event Simulation. Journal of IEEE, 1 (7), pp: 21852196.

Rukmana. H. R. 2008. Usaha Tani Jagung. Yogyakarta: Kanisius.

Rusastra, I Wayan dan Faisal Kasryno. Analisis Kebijakan Ekonomi Jagung Nasional. Jurnal Ekonomi Jagung Indonesia; Hal 255 - 287

Salvatore, Dominick. Ekonomi Internasional. Edisi Ketiga. Jakarta: Erlangga, 1997.

Santoso, Singgih. Statistik Parametrik Konsep dan Aplikasi dengan SPSS. Jakarta: PT. Elex Media Komputindo, 2014.

Singgih, Vita Agustitaria dan I Wayan Sudirman. Pengaruh Produksi, Jumlah Penduduk, PDB dan Kurs Dollar Terhadaap Impor Jagung Indonesia. E-Jurnal EP UNUD Vol 4, 2014; No. 2 : Hal. 71 - 79.

Sugiyono. Metode Penelitian Kauntitatif Kualitatif dan $R \& D$. Bandung: Alfabeta, 2012. 
Sukirno, Sadono. Makroekonomi Teori Pengantar. Edisi Ketiga. Jakarta: PT. RajaGrafindo Persada, 2011.

Surbakti, Michael N dan HM Mozart. Analisis Faktor - faktor yang Mempengaruhi Harga Jagung Pipil ditingkat Produsen Sumatera Utara. Jurnal Agribisnis USU, 2013.

Syamsi. 2012. Permintaan dan Penwaran Jagung Komoditas Pangan. Malang: Kementrian Pendidikan Nasional Universitas Brawijaya.

Tangendjaja, Budi, Yusmichad Yusdja, dan Nyak Ilham. Analisis Ekonomi Permintaan Jagung. Jurnal Ekonomi Jagung Indonesia; Hal 229 - 254.

Tillie, Pascal, Koen Dillen, Emilio Rodríguez-Cerezo. Modelling exante the economic and environmental impacts of Genetically Modified Herbicide
Tolerant maize cultivation in Europe. Agricultural Systems Elsevier Journal Vol 127, 2014. Hal: $150-160$.

Utomo Susilo. Dampak Impor dan Ekspor Jagung terhadap Produktivitas Jagung di Indonesia. Jurnal Etikonomi vol 11, 2012; No. 2: Hal 158 - 179

Widarjono, Agus. Analisis Statistika Multivariat Terapan. Yogyakarta: UPP STIM YKPN, 2010.

Zaini, Achmad. Pengaruh Harga Gula Impor, Harga Gula Domestik dan Produksi Gula Domestik Terhadap Permintaan Gula Impor di Indonesia. Jurnal Studi Agribisnis, EPP. Vol 5 No. 2. 2008. Hal 1-9 Samarinda: Fakultas Pertanian Universitas Mulawarman, 2008.

Zubachtirodin, M.S. Pabbage, dan Subandi. 2007. Wilayah Produksi dan Potensi Pengembangan Jagung. Balai Penelitian Tanaman Serealia. Bogor. 